Uniwersytet im. Adama Mickiewicza w Poznaniu

\title{
„Gatemania” jako przykład tabloidyzacji śledztw dziennikarskich
}

\author{
„There is no stopping the »gate« construction" \\ William Safire $^{1}$ \\ „Big or little, significant or silly, real or faux? \\ doesn't matter. It gets gated". \\ Rem Rieder ${ }^{2}$ \\ „It's the four-letter suffix \\ every public figure used to dread". \\ David Williamson ${ }^{3}$
}

\begin{abstract}
A lfred Harmsworth, znany również jako lord Northcliffe, brytyjski A potentat prasy drukowanej i wydawca „The Times” zapytany o definicję informacji powiedział, że ,jest nią to, co ktoś gdzieś chce ukryć. Wszystko inne jest reklamą"4 . Parafrazując owo stwierdzenie można bez wielkiej przesady powiedzieć, że „dziennikarstwo śledcze jest odkrywaniem prawdy o istotnych zagrożeniach życia publicznego. Wszystko inne jest gatemanią". Termin ten, zapożyczony na potrzeby tego artykułu od
\end{abstract}

1 William Safire on Politics and Language, transkrypt czatu z 23.04.2008, http:/www.washingtonpost.com/wp-dyn/content/discussion/2008/04/20/DI20080420 02124.html, 1.03.2012 (Nic nie powstrzyma konstrukcji z „gate” - tłum. autora).

2 R. Rieder, Gate of Hell, „American Journalism Review” June/July 2011 (Duzy lub mały, znaczacy lub głupi, prawdziwy czy zmyślony. To bez znaczenia. Staje się „,zagejtowany” - thum. autora).

D. Williamson, 'Gate' expectations are no longer what they used to be, 25.02.2010, http:/www.walesonline.co.uk/news/wales-news/2010/02/25/gate-expectations-are-no-longer-what-they-used-to-be-91466-25909175/, 11.03.2012 (Czteroliterowy przyrostek, którego boi się każda osoba publiczna - tłum. autora).

4 S. Bates, If No News, Send Rumors. Anecdotes of American Journalism, New York 1989, s. 52 (w oryginalnym brzmieniu: What somebody somewhere wants to suppress. All the rest is advertising). 
Davida Marsha ${ }^{5}$, opisuje zjawisko obecne w środowisku mediów od blisko czterech dekad. „Gatemania” sprowadza każde mniej lub bardziej bulwersujące i rozpoznane wydarzenie do miana skandalu, a powszechnie rozpoznawalny w tym kontekście przyrostek ,-gate” staje się elementem nadającym mu posmak sensacyjności. Nawyk kończenia w ten sposób nazw skandalizujących wydarzeń stosowany jest w mediach i polityce na całym świecie ${ }^{6}$. Powszechność jego użycia może prowadzić do powstania u odbiorców przekazów medialnych złudnego wrażenia, że świat relacji międzyludzkich na poziomie publicznym to jeden wielki, niekończący się ciąg skandali, który z racji swojej intensywności i wszechobecności uzyskuje status patologii społecznej. W tym przypadku media jawią się jako jedyna instytucja bez skazy z heroizmem odkrywająca przed opinią publiczną nie tylko rzutujące na bieg spraw państwa przypadki nadużywania władzy bądź niewłaściwego, partykularnego posługiwania się przez rządzących środkami przynależnymi im z racji zajmowanych stanowisk, ale również odsłaniająca zwyczajne, ludzkie wady osób z pierwszych stron gazet, które - choćby były tylko luźno związane z charakterem pełnionych przez nie obowiązków - mają świadczyć o ich szkodliwym wpływie na zaistniałą sytuację. Prezentacja w mediach rozlicznych kwestii z życia publicznego w taki właśnie sposób determinuje uproszczone i, co trzeba podkreślić, zdeformowane postrzeganie rzeczywistości przez odbiorców.

Zdaniem autora jeszcze większą szkodę tego typu narracja przysparza dziennikarstwu śledczemu. Ten rodzaj uprawiania profesji zaliczanej do zawodów publicznego zaufania uważany jest nie bez powodu za jedną z najskuteczniejszych form realizowania funkcji kontrolnej (watchdog function of the press). Dziennikarskie dochodzenia demaskujące rzeczywiste patologie władzy, wielkiego biznesu czy biurokracji najpełniej realizują nieformalną kontrolę społeczną tak ważną w przeciwdziałaniu oligarchizacji i ,zepsuciu” instytucji w państwie. Dalekosiężne skutki pracy reporterów śledczych, wywołujące od wielu dekad poważne zmiany legislacyjne, personalne i społeczne stały się synonimem potęgi prasy, nazywanej potocznie „czwartym stanem” lub „czwartą władzą”. Kilkusetletnia tradycja dochodzeń dziennikarskich stanęła jednak w ob-

5 D. Marsh, Mind Your Language, „The Guardian”, 1.02.2010.

6 Więcej na temat dziennikarstwa śledczego i związanego z tym skandalizowania wydarzeń ze świata polityki w: W. Adamczyk, W oparach skandalu: śledztwa dziennikarskie i ich rola w polityce, ,Tematy z Szewskiej” 2011, nr 2(6), s. 53-60. 
liczu zagrożenia ze strony zjawiska „gatemanii”, które staje się nagminną praktyką dziennikarzy i mediów nieuprawiających dociekliwej żurnalistyki. Maniera dodawania przyrostka „-gate” obserwowana jest nie tylko w odniesieniu do prawdziwych śledztw dziennikarskich, ale równie często wykorzystywana przez tabloidy i to w wielu krajach na całym świecie.

„Wykorzystanie słowa »gate« już dawno przestało być wyłącznie
domeną języka angielskiego. Używa się go do nadania pejoratywne-
go znaczenia także wydarzeniom w Polsce i na Węgrzech. Odnosi
się jednak wrażenie, że dodanie słowa »gate« niesie ze sobą przekaz,
iż taki skandal wiąże się z wiékszym ryzykiem politycznym, niż
zwykła afera bez tej końcówki»”.

Uzupełnianie przyrostkiem „-gate” nazw odnoszących się do zdarzeń o zróżnicowanej wartości informacyjnej stanowi formę przerysowania, swego rodzaju hiperboli sugerującej obcowanie z poważnym i niecodziennym wydarzeniem (bo przecież każde wydarzenie jest zdarzeniem, ale nie każde zdarzenie jest wydarzeniem). W ten sposób zaciera się granica między faktycznym odkrywaniem skrywanych przed opinią publiczną istotnych faktów mogących stanowić dowód na łamanie prawa lub naruszenie moralności przez wpływowe osobistości w państwie a skandalizacją drugorzędnych zachowań osób znanych, w tym również celebrytów, pozostających bez znaczącego wpływu na sprawy ważne dla obywateli. Prowadzi to nieuchronnie do powstania „Idiot Culture” (,kultury idiotów"), jak nazywa ten stan Carl Bernstein, jeden z dwóch sławnych reporterów „The Washington Post”, którzy ujawnili aferę Watergate. Zwraca on tym samym uwagę na szkodliwy charakter niektórych praktyk współczesnego dziennikarstwa. C. Bernstein „ostrzega przed głodną celebrytów, sensacji i skandali maszyną, która zużywa porządnych dziennikarzy" 8 .

Celem tych rozważań jest próba odpowiedzi na kilka pytań związanych ze zjawiskiem ,gatemanii”. Jakie względy przesądzają o oznaczeniu przez redakcje przyrostkiem ,-gate” często banalnych zdarzeń? Czy istnieją klarowne kryteria pozwalające rozróżnić wśród wydarzeń relacjonowanych przez prasę przypadki godne nawiązania do afery Water-

7 Nic nie powstrzyma konstrukcji $z$,,gate”, http://antykorupcja.edu.pl/index.php?mnu=113\&id=4360, 12.08.2010.

M. C. Ehrlich, The Journalism of Outrageousness: Tabloid Television News vs. Investigative News, „Journalism \& Mass Communication Monographs” 1996, no. 155 . 
gate za pomocą wspomnianego przyrostka od pospolitych incydentów pozbawionych jakichkolwiek elementów dziennikarstwa śledczego? Czy należy traktować stosowanie przyrostka ,-gate” jako formy wzmocnienia potrzeby publikacji skandalizujących treści przez media? Jakie skutki dla wiarygodności śledztw dziennikarskich pociąnnie za sobą zbyt częste wykorzystywanie przyrostka ,-gate”?

Profesję dziennikarską na świecie uprawiają tysiące, powszechnie znanych i cenionych reporterów jest niewielu. To między innymi sprawia, że obserwujemy od dziesięcioleci wzmożony pęd ku sławie wśród ludzi mediów. W osiągnięciu celu mają im pomóc różne zabiegi przyciągające uwagę odbiorców, która stanowi współcześnie najbardziej deficytowe i jednocześnie najbardziej pożądane dobro w świecie masowej informacji ${ }^{9}$. Jedną $\mathrm{z}$ metod skupienia zainteresowania audytoriów jest bez watpienia epatowanie skandalem - prawdziwym czy fikcyjnym, brzemiennym w skutki czy błahym i pospolitym ${ }^{10}$. Tabloidyzowanie ${ }^{11}$

9 B. Baybar-Hawks, The Impact of Investigative Journalism on Public Opinion and Policymaking, http://www.hichumanities.org/AHProceedings/Banu\%20Baybars-Hawks1.pdf, 10.03.2011.

10 Jak zauważyli Peter Golding and Philip Elliott: „Nie ma sensu uprawianie poważnego, pomocnego, szlachetnego dziennikarstwa jeśli publiczność rejestruje je jako nudę. Tak więc rozrywka jest wysoko na liście wartości informacyjnych zarówno jako cel sam w sobie, jak i środek do osiagnięcia innych dziennikarskich ideałów" (P. Golding, P. Elliott, News values and news production, w: Media studies: A reader, red. P. Marris, S. Thornham, New York 2000, s. 635).

11 Pojęcie oraz zjawisko tabloidyzacji zostało w literaturze przedmiotu dokładnie przeanalizowane (S. Zhou, Explicating Sensationalism in Television News: Content and the Bells and Whistles of Form, „Journal of Broadcasting \& Electronic Media”, September 2001; J. Atkinson, Tabloid Journalism, „Encyclopedia of International Media and Communications" 2003, vol. 4; H. Kutrz, Media Circus - The Trouble with America's Newspapers, New York 1994; P. Golding, P. Elliott, News values and news production, w: Media studies: A reader, red. P. Marris, S. Thornham, New York 2000; R. G. Picard, The Economics of Tabloidization: Observations From the British and American Experiences, presented to Euricom Colloquim on Tabloidization, University of Westminster, 9-13.09.1998; S. M. Bessie, Jazz Journalism: The Story of the Tabloid Newspapers, New York 1969; D. Cohen, Yellow Journalism: Scandal, Sensationalism, and Gossip in the Media, Twenty First Century Books 2000; N. R. Harris, Tabloidization in Modern American Press: A Textual Analysis 
and Assessment of Newspaper and Tabloid Coverage of the „Runaway Bride” Case, Georgia State University 2005; Communication Theses, Paper 7, http://digitalarchive.gsu.edu/communication theses/7, 10.03.2011; F. Esser, Tabloidization of News, „European Journal of Communcation” 1999, vol. 14, no. 3; R. E. Hiebert, Sh. J. Gibbons, Exploring Mass Media for Changing World, London 2000; S. Malovic, G. Vilovic, Tabloidization Conquers Quality Press, w: Quality Press in Southeast Europe, red. O. Spassov, Sofia 2004; A. Hirdman, M. Kleberg, K. Widestedt, Presentation of the research program. The Intimization of Journalism. Transformations of Medialized Public Spheres from the 1880s to Current Times, „Nordicom Review” 2005, no. 2; Justice G. N. Ray, Tabloidization of the Media: The Page Three Syndrome, Address by Mr. Justice G. N. Ray, Chairman, Press Council of India at Seminar organised by the Public Relations Society of India and Mass Media Centre, Government of West Bengal on August 25, 2006 at the Abaninddra Sabhaghar, Kolkata; N. Day, Sensational TV. Trash or Journalism?, Enslow Publishers 1996; H. Örnebring, A. M. Jönsson, Tabloid Journalism and the Public Sphere: a Historical Perspective on Tabloid Journalism, „Journalism Studies” 2004, vol. 5, no. 3; B. Franklin, Newszak \& News Media, London 1997; L. Jr. Washington, Facts, Fallacies, and Fears of Tabloidization, „USA Today Magazine” November 1, 1999, vol. 128, issue 2654; S. E. Bird, News We Can Use: An Audience Perspective on the Tabloidization of News in the United States, ,The Public” 1998, vol. 5 (3); G. Lăzăroiu, Tabloid Journalism and News Quality, „Economics, Management, and Financial Markets" 2007, vol. 2, issue 4, s. 200; T. Mayes, Submerging in Therapy News, „British Journalism Review” 2000, vol. 11, issue 4; Y. Inoue, Y. Kawakami, Factors Influencing Tabloid News Diffusion: Comparison with Hard News, „Keio Communication Review" 2004, no. 26; I. Connell, Mistaken Identities: Tabloid and Broadsheet News Discourse, „The Public” 1998, vol. 5, issue 3; M. D. Smith, The Tabloidization of the American Media. Troubled Franchise, "The New Republic" z 22.08.2005; K. Schoenbach, Does Tabloidization Really Make Newspaper Successful? A Summary of An Explorative Study, paper submitted to the Mass Communication and Society Division for presentation at the annual convention of the Association for Education in Journalism Communication, New Orlean, August 1999; A.-K. Oikarinen, Tabloidization and the Media. News vs Gossip: Does it Matter if the Line Disappears?, 2000, http://www.uta.fi/ anna-kaisa.oikarinen/wwwwork/page.htm, 10.01.2008; U. Klein, Tabloised Political Coverage in Bild-Zeitung, „The Public” 1998, vol. 5, issue 3; D. J. Krajicek, Scooped! Media Miss Real Story on Crime While Chasing Sex, Sleeze, and Celebrities, New York 1998; E. Rapping, The Tabloidization of Mainstream Media, „UBtoday”, Fall 2005; D. Rooney, Dynamics of the British Tabloid Press, ,The Public” 1998, vol. 5, issue 3; S. Allan, Kultura newsów, Kraków 2006; W. Adamczyk, Tabloidyzacja mediów mainstreamowych: przyczyny i konsekwencje, „Przegląd Politologiczny” 2008, nr 1; D. Piontek, Komunikowanie polityczne i kultura popularna. Tabloidyzacja informacji o polityce, Poznań 2011). Howard Kurtz definiuje tabloidyzację jako zmniejszenie ilości twardych informacji, takich jak polityka i ekonomia, i jednoczesny wzrost ilości miękkich informacji, takich jak sensacja, skandal i rozrywka (A. Pensar, Displaying Tabloidiza- 
tion. Analysis of Dagens Nyheters media coverage on the schoolshootings of Dunblane and the school hostage drama of Beslan, „Political Sciense - Media \& Politics", Stockholm University, C-Paper, January 2006). Według Roberta G. Picarda „mówiąc o tabloidyzacji należy uznać, że obejmuje ona zasięgiem zawartość, styl i prezentacje wyborów, w których tradycyjne wartości i styl informacji są nieobecne. W jej ekstremalnej postaci oznacza ona sensacjonalizm w skrajnym wydaniu, emocjonalną prezentację i unikanie problemów współczesności (eskapizm). W lżejszej odmianie tabloidyzacja zaciera różnice między informacją a rozrywką, kładzie nacisk na przyjemne doniesienia i sprawy ogólnoludzkie przy jednoczesnym przedstawianiu tematu w możliwie najsympatyczniejszy dla odbiorców sposób". Główny nacisk położony jest na emocjonalny sposób prezentacji informacji (forma) i elementy rozrywki (treść). George Juergens wskazuje na trzy wymiary sensacyjności publikacji medialnych: nacisk na charakter osobisty, preferowanie informacji trywialnych, a nie ważnych, używanie kolokwialnego, spersonalizowanego języka. Pierwszy wymiar wprost prowadzi do zmiany perspektywy postrzegania opisywanych spraw, ze społecznej na jednostkową. W konsekwencji przekazy stają się doniesieniami pozbawionymi istotności dla ogółu, koncentrując się na sprawach niecodziennych, rozbudzających emocje, lecz niewpływających na jakość życia (choćby podejmowanych przez jednostki decyzji). Owemu przesunięciu priorytetów według Nicholi Renee Harris, towarzyszy przemieszczenie granicy dobrego smaku w różnych formach wypowiedzi medialnej, tak charakterystyczne dla tabloidów. W literaturze przedmiotu można wyodrębnić co najmniej trzy odmienne ujęcia terminu tabloidyzacja. W pierwszym pojęcie to opisuje zmiany zachodzące w dziennikarstwie informacyjnym, dzięki którym rozrywka zastępuje poważne dziennikarstwo newsowe. Cechami charakteryzującymi tak postrzeganej tabloidyzacji są: 1) zmniejszające się zainteresowanie polityka, ekonomią i sprawami społecznymi, a skupienie uwagi na sporcie, skandalach i masowej rozrywce oraz 2) pobudzenie zainteresowania życiem prywatnym i sferą osobistą (bez względu na to, czy dotyczy to tak zwanych medialnych osobowości). W drugim ujęciu termin ten opisuje przesunięcie priorytetów w mediach z informacji i newsów na rozrywkę, czego przykładem są telewizje publiczne, walczące o widza na skomercjalizowanym rynku sposobami mediów prywatnych. Trzecie z ujęć tabloidyzacji zwraca uwagę na zachodzącą w mediach zmianę smaku w różnych formach przekazu. Można to zaobserwować choćby na przykładzie dyskusji politycznych, którym nadaje się formę talk-show, gdzie zwykli ludzie mówią o ich osobistym doświadczeniu i problemach, a nie o sprawach ważnych dla ogółu. Każe to postawić pytanie o obowiązujące standardy prowadzenia debaty publicznej i skalę ingerencji w sferę prywatną jednostki. Z kolei Frank Esser analizuje to pojęcie na dwóch poziomach. Pierwszy, nazywany przez niego poziomem mikro, sprowadza się do postrzegania tabloidyzacji jako zjawiska medialnego. Prowadzi ono do korekty tradycyjnych gazet i innych medialnych formatów, co w konsekwencji nakierowuje je na preferencje odbiorców i stricte komercyjne wymagania. Natomiast na poziomie makro tabloidyzacja oznacza zjawisko społeczne, symbolizujące główną zmianę w zakresie składu społeczeństwa. Znaki, którymi posługują się media, w coraz większym stopniu służa, na przykład, marketingowi 
przekazów, łączące skandalizowanie formy i treści z upraszczaniem rzeczywistości często do granic absurdu dotyka niemal bez wyjątków wszystkich sfer opisywanych w mediach. Zjawisko to obserwowane jest nawet w odniesieniu do dziennikarstwa śledczego, które najdłużej opierało się tym negatywnym trendom. Pierwiastek skandalu, obecny w publikacjach reporterów śledczych, pełni bowiem inna rolę. Jest środkiem poruszenia sumienia opinii publicznej, wywołania jej gwałtownej reakcji na ujawnione w wyniku dochodzeń dziennikarskich przypadki rażącego nadużywania władzy, niegospodarności, korupcji, nepotyzmu oraz innych patologii instytucji władzy i biznesu, a także zachowań osób publicznych, których nie da się pogodzić z akceptowanymi społecznie standardami w zakresie moralności. Wywołane w ten sposób niezadowolenie społeczne połączone $\mathrm{z}$ dezaprobatą wobec konkretnych ludzi, decyzji czy zjawisk może i powinno inicjować działania stosownych władz, zmierzające do usunięcia „usterki” w systemie oraz ukarania winnych. Dobrym przykładem ilustrującym specyfikę skandalu wywołanego w tym celu jest prowokacja angielskiego redaktora „Pall Mall Gazette", Williama Thomasa Steada z 1885 roku. Poruszony licznymi w tamtym czasie przypadkami prostytucji wśród osób nieletnich i handlu młodymi dziewczętami postanowił zaangażować się w działania na rzecz nowelizacji prawa karnego, które wyeliminowałyby, a przynajmniej w dużym stopniu ograniczyłyby ten naganny proceder. Poruszony bezradnością parlamentu postanowił sprowokować publiczną debatę w tej sprawie. Uczynił to w sposób niecodzienny. Za pięć funtów kupił 13-letnią Elizę Armstrong od jej matki alkoholiczki, która wiedziała, że córka zostanie zabrana do domu publicznego. Po bardzo krótkim pobycie w miejscowym domu rozkoszy dla zamożnych londyńczyków została przez W. T. Steada wywieziona do Francji, gdzie znalazła się pod opieką zaprzyjaźnionej rodziny z Armii Zbawienia. Perypetie E. Armstrong redaktor „Pall Mall Gazette” opisał w serii artykułów (ukazały się między 6 a 8 lipca 1885 roku) pod wspólnym tytułem The Maiden Tribute of Modern Babylon ${ }^{12}$. Ujawniona przez W. T. Steada obłuda rządzących i możnych oraz skorumpowanie miejscowej policji wywo-

politycznemu, a w mniejszym edukacji obywateli, co w efekcie może doprowadzić do pogłębienia się stanu alienacji w społeczeństwie.

W. T. Stead, The Maiden Tribute of Modern Babylon: the Report of our Secret Commission, ,The Pall Mall Gazette”, 6-8.07.1885, www.attackingthedevil.co.uk/ pmg/tribute/mt1.php, 7.03.2011. 
łało skandal i publiczną debatę. Jej efektem była zmiana obowiązującego w tym zakresie prawa (uchwaloną w sierpniu 1885 roku nowelę prawa karnego nazwano „ustawą Steada”). Autor publikacji trafił natomiast na trzy miesiące do więzienia za porwanie E. Armstrong. Jak zauważył John B. Thompson, w tej sprawie udało się pokazać, że reporterzy pełniąc rolę śledczych mogą przyczynić się do demaskacji skrywanej przed społeczeństwem prawdy i tym samym wywołać poprzez debatę publiczną oczekiwane zmiany ${ }^{13}$. Widać zatem na tym przykładzie, że skandal w dziennikarstwie śledczym pełni służebną rolę wobec nadrzędnego celu - inaczej, niż dzieje się to choćby w dziennikarstwie tabloidowym. W tym ostatnim na porządku dziennym jest skandalizowanie zarówno formy przekazu, jak i treści, a wywołanie skandalu jest celem samym w sobie ${ }^{14}$.

Znakiem czasu, wskazującym na postępującą ekspansję tabloidyzowania przekazów również w mediach mainstreamowych (dominującego nurtu) jest zjawisko tak zwanej ,gatemanii”. Pomimo dużej liczby dochodzeń reporterów śledczych, jakie zna historia dziennikarstwa, dopiero od czasów skandalu Watergate w nazwie wielu z nich funkcjonuje przyrostek „-gate”. Za twórcę tej maniery uważany jest William Lewis Safire $^{15}$. Począwszy od 1974 roku opatrywał on takim właśnie przyrost-

13 J. B. Thompson, Skandal polityczny. Władza i jawność w epoce medialnej, Warszawa 2010, s. 74.

${ }^{14}$ Więcej na temat podobieństw oraz różnic pomiędzy dziennikarstwem śledczym a tabloidowym zob.: W. Adamczyk, Skandal na pierwszej stronie. Sensacyjność jako element oceny wiarygodności śledztw dziennikarskich, w: $O$ dziennikarstwie śledczym. Normy, zagrożenia, pespektywy, red. M. Palczewski, M. Worsowicz, Łódź 2009, s. 38-40; M. C. Ehrlich, The Journalism of Outrageousness: Tabloid Television News vs. Investigative News, op. cit.

15 William Lewis Safire (17.12.1929-27.09.2009), amerykański dziennikarz, publicysta, autor książek. Karierę dziennikarską zaczynał w „The New York Herald”. W czasach prezydentury Richarda Nixona był członkiem zespołu autorów przemówień głowy państwa. Od 1973 zatrudniony w „The New York Times” jako felietonista. Od 1979 roku W. L. Safire miał swoją rubrykę „On Language” w „NYT Magazine”, dzięki której stał się jednym z najbardziej znanych i najchętniej czytanych autorów piszących o meandrach języka angielskiego. W 1978 roku zdobył nagrodę Pulitzera za komentarz w sprawie rzekomych nieprawidłowości budżetowych związanych z bliskim współpracownikiem prezydenta Jimmiego Cartera, Bertem Lance'em. Od 1995 roku był członkiem kapituły nagrody Pulitzera. W 2006 roku otrzymał z rąk prezydenta Georga W. Busha najwyższe cywilne odznaczenie USA, Medal Wolności. W swojej zawodowej karierze współpracował również jako producent $\mathrm{z}$ telewizją, był korespondentem wojennym oraz szefem firmy $\mathrm{z}$ branży PR 
kiem „-gate” zdarzenia publiczne o różnym ciężarze gatunkowym, co zdaniem niektórych - miało umniejszyć znaczenie przestępstw popełnionych przez R. Nixona ${ }^{16}$. John B. Thompson nazywa to zjawisko „syndromem skandalu”, rozumiejąc pod tym pojęciem samoodnawialny oraz samowzmacniający się proces kształtowany przez konkurencję i rywalizację na rynku mediów i polityki, prowadzący do kreowania coraz to nowych skandali. Te ostatnie koncentrują uwagę opinii publicznej na zmediatyzowanych formach prowadzenia debaty publicznej, jednocześnie marginalizując lub wręcz przesuwając na dalszy plan inne tematy, co rodzi kryzysy polityczne, które mogą osłabić lub nawet sparaliżować władze $^{17}$. Takie redukowanie informacji do serii sloganów i skandali przyczynia się do tworzenia nieustannego „klimatu politycznego kryzysu", a to zubaża publiczną debatę ${ }^{18}$. Jak zauważył Alexander Heffner,

„Dodawanie przyrostka »-gate« stało się łatwym i wprowadzającym w błąd sposobem na oznaczenie politycznego skandalu. [...] Ale używając »-gate« do opisania byle dochodzenia lub skandalu dziennikarze zacierają różnice pomiędzy poważnymi przypadkami naruszeń publicznego zaufania a mniej alarmującymi - często osobistymi - incydentami” $" 19$.

Zjawisko tworzenia wyrazów z przyrostkiem ,,-gate” zostało również zauważone przez językoznawców i doczekało się kilku interesujących

w Nowym Jorku (opracowano na podstawie: Columnist Biography: William Safire, www.nytimes.com/ref/opinion/SAFIRE-BIO.html, 10.03.2012; H. Kurtz, William Safire to End Op-Ed Run AT N.Y. Times, „The Washington Post”, 16.11.2004; R. D. McFadden, William Safire, Political Columnist and Oracle of Language, Dies at 79, „The New York Times” 28.09.2009; Presidential Medal of Freedom Recipients, www. senate.gov, 10.03.2012).

${ }_{16}$ Nic nie powstrzyma konstrukcji $z$,gate”, http://antykorupcja.edu.pl/index.php?mnu=113\&id=4360, 12.08.2010.

17 J. B. Thompson, Political Scandal. Power and Visibility in the Media Age, „Polity Press” 2000, s. 265. Pojęcie „scandal syndrome” definiuje również James Stanyer. W jego opinii każda niedyskrecja polityków, każde naruszenie prawa, nawet najmniejsze jest przedstawiane jako skandal z dodatkiem przyrostka ,-gate”. Ma to wzmocnić wiarygodność relacji dziennikarskiej, choć większość takich przypadków nie ma cech starannego dochodzenia, jak to było w przypadku afery Watergate (J. Stanyer, Modern political Communication: mediated politics in uncertain times, „Polity Press” 2007, s. 59).

18 D. Marsh, Mind your language, „The Guardian”, 1.02.2010.

19 A. Heffner, The Anthony Weiner scandal doesn't merit a '-gate', „The Washington Post", 8.06.2011. 
opracowań zarówno w języku polskim, jak i w angielskim. Bogusław Kreja analizował ten słowotwórczy formant już na początku lat 90. XX wieku. W badanym przez niego okresie od października 1990 roku do czerwca 1993 roku doliczył się w polskiej prasie ponad trzydziestu przypadków świadczących o swego rodzaju modzie na tak zwane „gejty” w nazwach rozmaitych skandali ${ }^{20}$. Wszystkie one miały swoje źródło językowe w aferze Watergate, a ich imponująca liczba była wynikiem zmian sytuacji polskiej prasy tamtych lat.
„Odpowiednio nagłośnione nazwy Watergate i później Irangate do- starczyły prasie pewnego wzoru, modelu, który pomógł wszystkie zjawiska o charakterze afery objąć pewnym wspólnym mianowni- kiem - formantem słowotwórczym o ogólnej funkcji 'afera', co dało początek dość licznemu typowi słowotwórczemu. W Polsce formant ten się uaktywnił i upowszechnił w zasadzie dopiero wtedy, gdy pra- sa uzyskała możliwość swobodnego pisania o wszystkim, a więc i o różnego rodzaju aferach, a że ich w pierwszym okresie naszej no- wej sytuacji polityczno-gospodarczej było szczególnie dużo, więc i formacji na -gate w naszej prasie się namnożyło"21.

Twórca maniery dodawania „-gate” do nazw wydarzeń opisywanych przez media, W. L. Safire, w swoim politycznym słowniku określił ją jako fortel, który ma stanowić złowieszczą etykietę ewentualnego skandalu. Dodał również, że owa konstrukcja jest zbyt przydatna, by przestać z niej korzystać ${ }^{22}$. W opinii I. Willis Russell i Mary Gray Porter przy pomocy tego przyrostka prasa opisuje skandale zawierające zarzuty o korupcję i tuszowanie sprawy ${ }^{23}$. Podobnie ocenia ten medialno-polityczny zabieg Jonathan Green. Według niego wykorzystanie w nazwie ,-gate" służy

20 B. Kreja, O formancie gate 'afera, skandal', „Język Polski” 1993, t. LXXIII, s. 63. Problematykę tę omawiały również: H. Jadacka, System stowotwórczy polszczyzny (1945-2000), Warszawa 2001, s. 93-99 (zaliczyła ona formacje z ,-gate” do compositiów, na przykład: Słupia-gate, wódka-gate); K. Waszakowa, Współczesne stowotwórstwo polskie i czeskie wobec ekspansji zapożyczeń, „Poradnik Językowy” 2002, z. 8, s. 9; R. Przybylska, O najnowszym stownictwie polskim, „Polonistyka” 2002, nr 9; K. Wyrwas, Rywingate i pracoholik - derywaty sufiskalne czy złożenia?, www.poradniajezykowa.pl/artykuly/KW_rywingate.pdf, 10.03.2012.

${ }^{21}$ B. Kreja, O formancie gate 'afera, skandal', op. cit., s. 68.

22 W. L. Safire, Safire's New Political Dictionary: the Definitive Guide to the New Language of Politics, New York 1993, hasło: ,-gate construction”, s. 278-279.

${ }^{23}$ I. W. Russell, M. Gray Porter, Among the New Words, „American Speech”, vol. 53, no. 3, Autumn 1978. 
„oznaczeniu skandalu charakteryzującego się zarzutami o ukrywanie $\mathrm{i}$ celowe zaciemnianie sprawy przez osoby zamieszane $\mathrm{w}$ ten proceder",24.

Tę myśl rozwijają autorzy Oxford English Dictionary wskazując na nowe zastosowanie tego przyrostka do żartobliwego oznaczenia wszelkiego rodzaju skandali, kontrowersji i przypadków bałaganu ${ }^{25}$. Zdaniem Granta Barretta „-gate” wskazuje na skandal, szczególnie obejmujący tuszowanie sprawy lub ukryte działania ${ }^{26}$. Na trwały charakter przyrostka zwraca uwagę Clarence Lewis Barnhart. Uważa on, że:

„-gate jako forma utrzymuje się $\mathrm{w}$ dalszym ciagu pomimo krótkiego życia większości kreacji, które z niego korzystały" ${ }^{\text {"27 }}$.

W The Concise New Partridge Dictionary of Slang and Unconventional English określono przeznaczenie „-gate” jako formy używanej w charakterze ozdobnika rzeczownika lub nazwy sugerującej daleko idący skandal polityczny ${ }^{28}$. Jeszcze dalej idzie w swoich rozważaniach Margaret H. DeFleur, która wskazuje nie tylko na polityczny wątek podnoszony w relacjach tytułowanych przez media w ten sposób, ale również zawierających elementy kryminogenne.

„Termin gate stał się przyrostkiem wskazującym na domniemany skandal z udziałem polityków. [...] Istotne demaskacje są teraz prawie zawsze kojarzone jako »smoking guns «"29.

Wskazane powyżej przykłady nie rozstrzygają jednoznacznie, do jakiego typu wydarzeń przypisany jest ten przyrostek. Poza sferą polityki

24 J. Green, Dictionary of Jargon, Routledge 1987, Appendix A - Suffixes, s. 606.

25 The 'gate' suffix, Oxford English Dictionary, http://www.oed.com/public/gatesuffix/the-gate-suffix, 9.03.2012. We Włoszech, na przykład, do oznaczenia wydarzeń o charakterze skandalu oprócz ,-gate” wykorzystuje się również przyrostek „-poli” (Tangentopoli, Affitopoli, Esamopoli, Calciopoli).

26 G. Barrett, Hatchet jobs and hardball: the Oxford dictionary of American political slang, Oxford Press 2004; „The -gate to scandal”, s. 17-18.

27 C. L. Barnhart, Second Barnhart Dictionary of New English, Barnhart Books 1980 , s. 18.

28 The Concise New Partridge Dictionary of Slang and Unconventional English, red. T. Dalzell, T. Victor, Routledge 2008, s. 282.

29 M. H. DeFleur, Computer-Assisted Investigative Reporting. Development and Methodology, Lawrence Erlbaum, New Yersey 1997, s. 16. Określenie „smoking guns" oznacza działanie mające związek z przestępstwem (przyp. autora). 
nie wykluczono innych dziedzin życia osób i instytucji publicznych, co stwarza szerokie pole wykorzystania tej formuły.

Interesująco przedstawia się również etymologia zastosowania tego przyrostka. Jak podają autorzy Merriam-Webster's dictionary of allusions w XVIII wieku w Irlandii ,-gate” zostało wykorzystane do utworzenia pseudonimów członków rodziny szóstego hrabiego Barrymore. Jego najstarszy syn, Richard, z powodu swojej rozrzutności otrzymał przezwisko „Hellgate” (umierając w wieku 24 lat miał na swoim koncie między innymi roztrwonienie rodzinnej fortuny wynoszącej 300000 funtów). Drugi w kolejności do spadku syn, Henry, urodził się ze zniekształconą stopą i z tego właśnie powodu otrzymał przydomek „Cripplegate”. Augustus, następny ze spadkobierców, został nazwany „Newgate”, co miało związek ze sławnym miejskim więzieniem, w którym obok przestępców swoje kary odbywali również dłużnicy. Ostatnia $\mathrm{z}$ rodu Barrymore, córka Caroline, zapamiętana jako wulgarna, młoda kobieta, otrzymała przydomek „Billingsgate”. Wszystkie z tych określeń, poza „Hellgate”, pochodziły od nazw bram w murach Londy$\mathrm{nu}^{30}$.

Od czasów afery Watergate doniesienia medialne, stanowiące relacje z prawdziwych lub domniemanych skandali często były opatrzone nazwą zawierającą przyrostek ,-gate”. James Lull i Stephen Hinerman wyróżnili trzy typy skandali medialnych:

1) instytucjonalne,

2) celebryckie,

3) psychodrama $^{31}$.

30 Hasło: „billingsgate”, E. Webber, M. Feinsilber, Merriam-Webster's dictionary of allusions, Merriam-Webster 1999, s. 65. Równie ciekawie przedstawia się etymologia samego terminu Watergate. Nazwa pierwotnie oznaczała śluzę, później kompleks apartamentów i biur w Waszyngtonie, by w efekcie stać się pojęciem kojarzonym z Watergate Affair lub w skrócie Watergate. Pisali o tym: K Wyrwas, $R y$ wingate i pracoholik - derywaty sufiskalne czy złożenia?, op. cit. oraz J. Kelly, Answer Man: A Gate to Summers Past, „The Washington Post”, 13.12.2004. John Kelly opisuje genezę nazwy Watergate, wywodząc ją w pierwszej kolejności od ujścia rzeki Potomac (bramy wodnej), później od nazwy restauracji „Water Gate Inn”, mieszczącej się na brzegu rzeki i wreszcie od miejsca corocznych koncertów na barce rzecznej (ostatni odbył się w 1965 roku).

31 J. Lull, S Hinerman, The Search for Scandal, w: Media Scandals. Morality and Desire in the Popular Culture Marketplace, red. J. Lull, S. Hinerman, New York 1997, s. 20. 
Z punktu widzenia przedmiotu tych rozważań na uwagę zasługują przede wszystkim skandale instytucjonalne, bowiem są one nierozerwalnie związane ze specyfiką prowadzonych przez dziennikarzy śledczych dochodzeń. Dwa pozostałe typy są jedynie uzupełnieniem i stanowią ilustrację współczesnego zainteresowania części mediów (głównie tak zwanej prasy kolorowej, adresowanej do kobiet oraz portali internetowych o charakterze plotkarskim), które w pogoni za sensacją mnożą quasi afery potęgując w ten sposób ciekawość odbiorców o niewyszukanych gustach. Jednocześnie stwarza się w ten sposób pozory obcowania z czymś niezwykłym, przy okazji oddziałując na emocje. Ten ostatni element dominuje w konwencji prezentacji zarówno w aferach dotyczących celebrytów, jak i psychodramach (skandalizująca forma i treść dotyczy moralnych zagrożeń zwykłych ludzi).

Spośród skandali medialnych, zawierających w nazwie przyrostek „-gate”, można wyróżnić trzy grupy posiadające odmienne cechy:

1) ze względu na miejsce skandalu (na przykład: Irangate, Dallasgate, Koreagate);

2) ze względu na nazwisko osoby lub instytucji zamieszanej w skandal, a także nazwę produktu (na przykład: Motorgate, Lewinskygate, Rathergate);

3) ze względu na treść skandalu (Wine-gate, Ice Cream gate, Peanutgate) ${ }^{32}$.

Przykładowe zestawienie skandali z przyrostkiem ,-gate” zawiera poniższa tabela (na potrzeby tego opracowania i dla większej przejrzystości podziału autor umieścił w jednej grupie afery dotyczące towaru lub prowadzonej działalności pod wspólnym szyldem ,ze względu na treść skandalu").

Tabela 1

Podzial skandali z suffixem -gate na wybranych przykładach

\begin{tabular}{||c|l|l||}
\hline \multicolumn{3}{|c||}{ Podzial skandali medialnych z przyrostkiem „-gate” } \\
\hline $\begin{array}{c}\text { Ze względu na miejsce } \\
\text { skandalu }\end{array}$ & $\begin{array}{c}\text { Ze względu na nazwisko } \\
\text { osoby lub nazwę instytucji } \\
\text { zaangażowanej w skandal }\end{array}$ & $\begin{array}{c}\text { Ze względu na treść skanda- } \\
\text { lu (towar lub rodzaj } \\
\text { dzialalności) }\end{array}$ \\
\hline \multicolumn{1}{|c|}{2} & \multicolumn{1}{c||}{3} \\
\hline Słupsk-gate & Floodgate & Wine-gate \\
\hline Dallasgate & Lancegate & Ice Cream gate \\
\hline
\end{tabular}

32 Welches $\sim$ gate nimmst du?, http://www.extraflach.de/blog/category/morphologie, 9.03.2012. 


\begin{tabular}{|c|c|c|}
\hline 1 & 2 & 3 \\
\hline Koreagate & $\mathrm{X}$-gate & Sznapsgate \\
\hline Jugogate & Komisja-gate & Trabantgate \\
\hline Kasynogate & Sarkogate & Marlborogate \\
\hline Floragate & SB-gate & Fonografgate \\
\hline Magdalenkagate & Guerragate & Aspirynagate \\
\hline Volgagate & Billygate & cuprumgate \\
\hline Parysgate & Dianagate (Squidgygate) & FOZZ-gate \\
\hline Okęcie-gate & Rywingate & Kasetagate \\
\hline Irangate & Olingate & Cytrynygate \\
\hline Milanogate & Henrygate & Tiwigate \\
\hline Vietgate & Kanyegate & Erosgate \\
\hline Iraqgate & Noemigate & Żarówa gate \\
\hline Whitewatergate & Plamegate & Rubel-gate \\
\hline Angolagate & Reutersgate & Oilgate \\
\hline Watergate & Tigergate & Agentgate \\
\hline Applegate & Genschergate & Afergate \\
\hline Donnygate & $\begin{array}{l}\text { Monicagate (Lewinskygate, } \\
\text { Zippergate, Sexgate, Tailgate) }\end{array}$ & Rubbergate \\
\hline Hollywoodgate & Camillagate & Nannygate \\
\hline Starachowicegate & Cheriegate & Climategate \\
\hline \multirow[t]{4}{*}{ Afganistangate } & Hillarygate & Memogate (Rathergate) \\
\hline & Newtgate & Nipplegate \\
\hline & Gurugate & Travelgate \\
\hline & Terrygate & Mozarellagate \\
\hline
\end{tabular}

Źródło: Opracowanie własne autora.

John B. Thompson zaproponował dodatkowo klasyfikację afer politycznych, w której wymienił:

1) skandale o podłożu seksualnym - cechuje je naruszenie zasad odnoszących się do relacji seksualnych;

2) skandale finansowe - dotyczą niewłaściwego wykorzystania zasobów ekonomicznych;

3) skandale związane z władzą - ich cechąjest nadużywanie władzy politycznej ${ }^{33}$.

33 J. B. Thompson, Skandal polityczny. Władza i jawność w epoce medialnej, op. cit., s. 152 . 
Na marginesie tej typologii warto zaznaczyć, że podział ten nie jest całkowicie klarowny, ponieważ w niektórych przypadkach meritum skandalu obejmuje dwa, a niekiedy nawet wszystkie trzy obszary. Dobrym przykładem jest choćby afera nazwana w 2010 roku przez brytyjskie media Irisgate. Bohaterką skandalu była członkini parlamentu i żona Pierwszego Ministra Irlandii Północnej, Iris Robinson (miała w 2008 roku 59 lat), której udowodniono nie tylko romans z młodszym o 40 lat młodym biznesmenem, Kirkiem McCambley, ale również finansowe nadużycia. Miała ona, jak wykazało śledztwo, pomóc mu w otrzymaniu od lokalnych deweloperów pożyczki na kwotę 50000 funtów na otwarcie restauracji. Transakcji tej I. Robinson nie tylko nie zgłosiła w parlamencie, dodatkowo przyjęła jeszcze w formie prezentu 5000 funtów od swego kochanka ${ }^{34}$. Zatem w tym przypadku skandal obejmuje wszystkie trzy obszary, które wzajemnie przenikają się.

Analizując związki pomiędzy skandalizowaniem przekazów w mediach a dziennikarstwem śledczym nie sposób nie dostrzec wyraźnych korelacji. Komponentami skandalu medialnego są w pierwszej kolejności zachowania stanowiące naruszenie powszechnie akceptowanych norm współżycia społecznego, które ze względu na swój szkodliwy charakter zatajone są przed opinią publiczną. Istotą skandalu jest więc upublicznienie treści będących wcześniej udziałem nielicznej grupy osób połączone z postawieniem konkretnych zarzutów (mogą one, o czym trzeba pamiętać na tym etapie postępowania, zawierać sugestie dotyczące domniemanych, a nie faktycznych czynów zakazanych). Efektem tak wywołanego skandalu jest zwykle niezadowolenie i dezaprobata opinii publicznej w stosunku do ujawnionych nieprawidłowości lub podejrzeń wobec osób publicznych. Modelowo można to przedstawić w następujący sposób (rys. 1).

Szukając analogii przebiegu skandalu medialnego do reporterskiego dochodzenia można odwołać się do znanego z literatury klasycznego modelu muckrakingu, ilustrującego sekwencję kolejnych etapów tej procedury (w tym porównaniu autor pozostawia bez komentarza dwa warianty tego modelu - skrócony i skokowego wpływu, których analiza

34 E. Addley, Iris Robinson and Kirk McCambley: a strange tale of Belfast's 'odd couple', „The Guardian” 8.01.2010; A. Jamieson, Iris Robinson expelled from DUP after financial row over affair with toyboy lover, „The Telegraph”, 9.01.2010; T. Crichton, Robinson fights for political life amidst Irisgate scandal, „The Herald" (Scotland), 8.01.2010. 


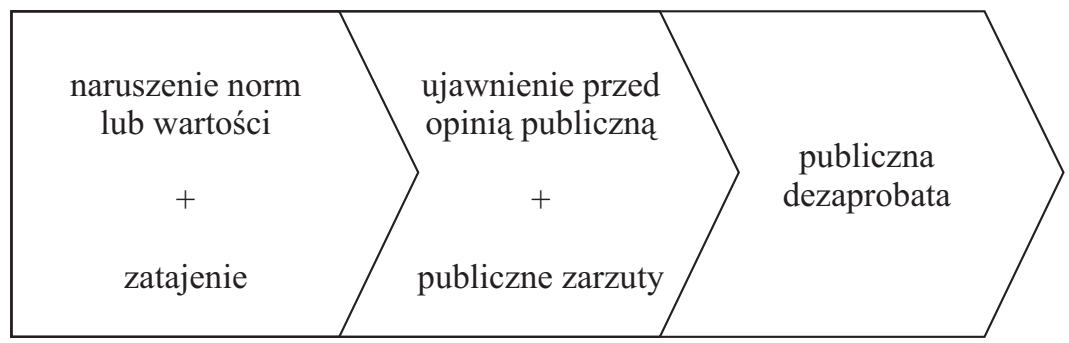

Rys. 1. Podstawowe składniki skandalu

Źródło: J. B. Thompson, Political Scandal. Power and Visibility in the Media Age, Polity Press 2000, s. 24.

w tym miejscu, ze względu na dużą liczbę modyfikacji tego procesu, zmniejszyłaby klarowność wywodu) ${ }^{35}$. W jego podstawowej postaci początkiem jest dziennikarskie śledztwo, którego jedną z cech szczególnych jest widoczny wkład pracy reportera, odkrywającego kolejne elementy bezprawnego lub amoralnego procederu. Ustalenia tego dochodzenia prezentowane są najczęściej w postaci cyklu publikacji, demaskujących szkodliwe zachowanie. Treści te z założenia powinny wzbudzić zainteresowanie odbiorców, przede wszystkim ze względu na omawianą tematykę i potencjalne lub rzeczywiste zagrożenie dla systemu. Reakcją na ujawnienie przez dziennikarza problemu jest zazwyczaj mobilizacja opinii publicznej. Odbiorcy, poruszeni wagą opisywanych zjawisk, wywieraja wpływ na instytucje władzy odpowiedzialne za utrzymanie porządku i bezpieczeństwa państwa oraz stanowienie prawa. Celem tej presji skierowanej na rządzących jest przede wszystkim powstrzymanie zdemaskowanego zjawiska patologicznego i podjęcie niezbędnych działań, które zapobiegłyby w przyszłości podobnym sytuacjom. Efektem nacisków wywieranych na władze są inicjatywy właściwych instytucji (legislacyjne, personalne, dyscyplinarne lub administracyjne). $\mathrm{W}$ ostatnim etapie tego modelu obserwujemy polityczne konsekwencje, które mogą przybrać formę nowych rozwiązań prawnych, rozstrzygnięć karnych lub dymisji. Graficznie procedurę tę przedstawiono poniżej (rys. 2).

35 Zob. H. L Molotch, D. L. Protess, M. T. Gordon, The Media-Policy Connection: Ecologies of News, w: Political Communication Research: Approaches, Studies and Assessments, vol. II, red. D. Paletz, Norwood 1996, s. 44-50. 


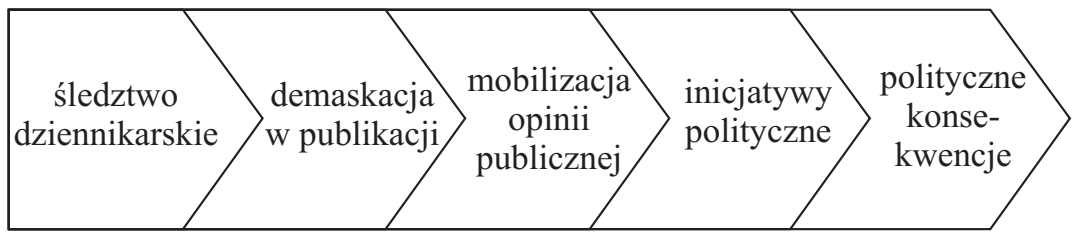

Rys. 2. Klasyczny model muckrakingu

Źródło: H. L Molotch, D. L. Protess, M. T. Gordon, The Media-Policy Connection: Ecologies of News, w: Political Communication Research: Approaches, Studies and Assessments, vol. II, red. D. Paletz, Norwood 1996, s. 44.

Zależność między poszczególnymi fazami obu procedur można przedstawić następująco (rys. 3).

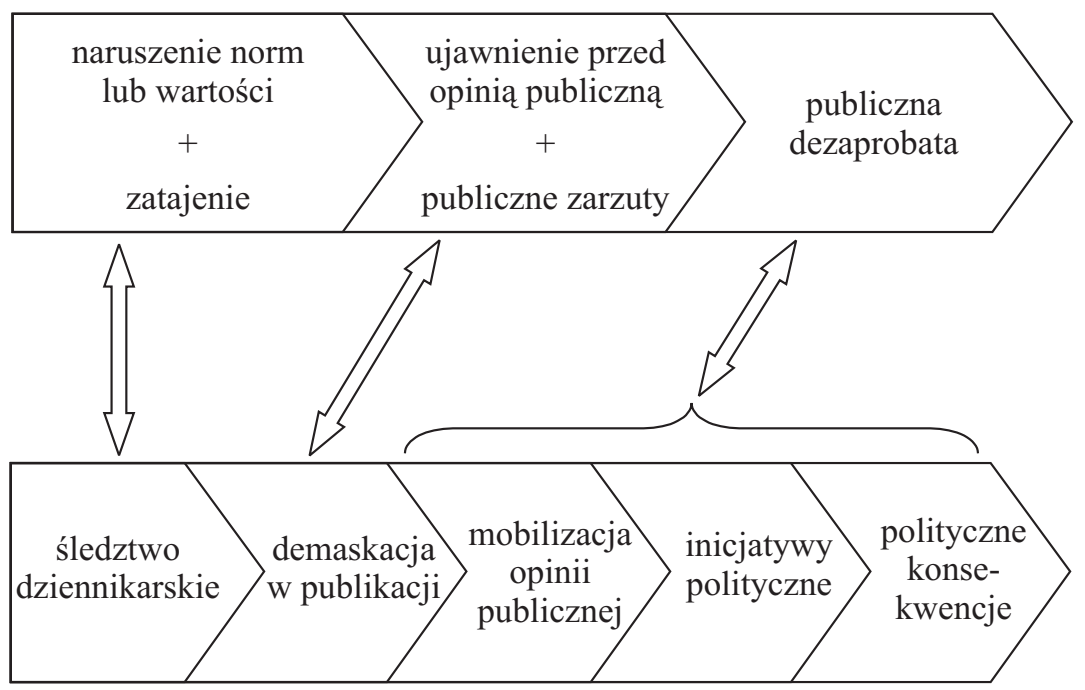

Rys. 3. Korelacja pomiędzy podstawowymi składnikami skandalu (u góry) a kolejnymi etapami $\mathrm{w}$ klasycznym modelu muckrakingu (na dole)

Źródło: Opracowanie własne.

Powyższe zestawienie pozwala zrozumieć rolę skandalu w dziennikarstwie śledczym. Szczególnie istotna jest świadomość, że publiczna dezaprobata powinna prowadzić do mobilizacji opinii, a następnie do pojawienia się inicjatyw i konsekwencji politycznych. W efekcie skandal jest środkiem służącym do realizacji nadrzędnych zadań, a nie celem samym w sobie, jak to się dzieje z reguły w dziennikarstwie tabloidowym. 
Przyjęcie takiej perspektywy oznacza zgodę na traktowanie skandalu jako immanentnej części dziennikarstwa śledczego, a zatem jednoczesne odrzucenie zarzutów o świadome sprowadzanie opisywanych zjawisk jedynie do miana afery.

Od czasów skandalu Watergate wyliczać można dziesiątki rozmaitych wydarzeń, które w relacjach medialnych nazywane były zgodnie z opisaną maniera poprzez dodanie przyrostka ,-gate” (Vietgate, Irangate, Whitewatergate, Plamegate ${ }^{36}$, Rywingate, Zippergate, Climategate, Memogate $^{37}$, Katrinagate). Wiele $\mathrm{z}$ nich wymienianych $\mathrm{w}$ literaturze to skandale obyczajowe, sportowe, szpiegowskie, z reguły dotyczące zdarzeń pozbawionych cech charakterystycznych dla procederów nagłaśnianych w śledztwach dziennikarskich. Co zatem odróżnia prawdziwe śledztwo dziennikarskie od relacji zawierającej skandalizujące treści i przestawionej w formule skandalu, choć opatrzonej tytułem z przyrostkiem ,-gate”, sugerującym odbiorcy szansę obcowania z poważnym materiałem prasowym? Zestawienie owych różnic, według Matthew J. Ehrlicha ${ }^{38}$, zawiera poniższa tabela.

Tabela 2

Różnice pomiędzy dziennikarstwem śledczym a tabloidowym

\begin{tabular}{|c|c|c|}
\hline & Dziennikarstwo śledcze & Dziennikarstwo tabloidowe \\
\hline 1 & 2 & 3 \\
\hline $\begin{array}{l}\text { Charakter } \\
\text { dzialalności }\end{array}$ & $\begin{array}{l}\text { Próbuje odkryć „usterkę w systemie”, } \\
\text { systemową obojętność, hipokryzję, } \\
\text { ujawnić zagrożenia ze strony biurokra- } \\
\text { cji lub zdemaskować źle działające in- } \\
\text { stytucje. }\end{array}$ & $\begin{array}{l}\text { Poprzestaje na portretowaniu winy } \\
\text { jednostki, a w konsekwencji w więk- } \\
\text { szym stopniu stara się wykazać osobi- } \\
\text { sty wpływ jednostki na pojawienie się } \\
\text { patologii. }\end{array}$ \\
\hline $\begin{array}{l}\text { Forma } \\
\text { wypowiedzi }\end{array}$ & $\begin{array}{l}\text { Reporterzy dochodzeniowi w znacznej } \\
\text { części przypadków operują gatunkami } \\
\text { z pogranicza dziennikarstwa i literatu- } \\
\text { ry, skupiając się bardziej na treści. }\end{array}$ & $\begin{array}{l}\text { Dziennikarze tabloidów dążą do jak } \\
\text { najatrakcyjniejszego przedstawienia ze- } \\
\text { branego materiału, stawiając przede } \\
\text { wszystkim na pomysłowość formy. }\end{array}$ \\
\hline
\end{tabular}

${ }^{36}$ Zob. W. Adamczyk, Dziennikarze a przecieki kontrolowane. Przypadek Judith Miller z New York Times, w: Media dawne i wspótczesne, red. B. Kosmanowa, t. 1, Poznań 2006.

${ }^{37}$ Zob. W. Adamczyk, Dziennikarskie skandale a wiarygodność przekazów medialnych, w: Studia nad mediami i komunikowaniem masowym. Prawo - Jezzyk - Tekst, red. J. Fras, Torun 2007.

${ }^{38}$ M. J. Ehrlich, The Journalism of Outrageousness: Tabloid Television News vs. Investigative News, op. cit. 


\begin{tabular}{|c|c|c|}
\hline 1 & 2 & 3 \\
\hline Cel & $\begin{array}{l}\text { Dziennikarstwo śledcze wykorzystuje } \\
\text { demaskacje patologii jako środek do } \\
\text { wywołania skandalu, który pobudzi } \\
\text { odbiorców i wywrze presję na władzę. }\end{array}$ & $\begin{array}{l}\text { Dla tabloidów skandal jest celem sa- } \\
\text { mym w sobie, bo skupia uwage nie } \\
\text { tyle na problemie, co na samym me- } \\
\text { dium, a przez to pozwala zwiększyć } \\
\text { dochody. }\end{array}$ \\
\hline $\begin{array}{l}\text { Wspólpraca } \\
z \text { poufnymi } \\
\text { informato- } \\
\text { rami }\end{array}$ & $\begin{array}{l}\text { W środowisku reporterów dochodze- } \\
\text { niowych płacenie za informację, jako } \\
\text { forma gratyfikacji dla informatora, nie } \\
\text { występuje, ponieważ jest to nie tylko } \\
\text { wattiiwe etycznie, ale przede wszyst- } \\
\text { kim podważa wiarygodność źródła. }\end{array}$ & $\begin{array}{l}\text { Dziennikarze tabloidów bardzo często } \\
\text { płacą za sensacyjne informacje do- } \\
\text { tyczące życia celebrity lub przejawów } \\
\text { patologii w instytucjach politycznych. }\end{array}$ \\
\hline $\begin{array}{l}\text { Dobór infor- } \\
\text { matorów }\end{array}$ & $\begin{array}{l}\text { Reporterzy śledczy selekcjonują infor- } \\
\text { matorów pod względem ich przydat- } \\
\text { ności w rozwinięciu problematyki } \\
\text { przygotowywanych publikacji. }\end{array}$ & $\begin{array}{l}\text { Dla dziennikarzy tabloidów podstawo- } \\
\text { wym kryterium wykorzystania źródła } \\
\text { są jego możliwości w dostarczeniu jak } \\
\text { najbardziej pikantnych szczegółów z ży- } \\
\text { cia rozpracowywanej osoby. }\end{array}$ \\
\hline $\begin{array}{l}\text { Długość } \\
\text { pracy nad } \\
\text { materiałem }\end{array}$ & $\begin{array}{l}\text { Dla reporterów dochodzeniowych } \\
\text { normą są tygodnie, a często i miesiące } \\
\text { poświęcone na badanie tematu oraz } \\
\text { weryfikację zebranych informacji. }\end{array}$ & $\begin{array}{l}\text { Dziennikarze tabloidowi, walczący z pre- } \\
\text { sją czasu i konkurencją, nie mogą zbyt } \\
\text { długo zajmować się jedną sprawą. }\end{array}$ \\
\hline $\begin{array}{l}\text { Źródla } \\
\text { informacji }\end{array}$ & $\begin{array}{l}\text { W dziennikarstwie śledczym są nimi } \\
\text { akta spraw sądowych, dokumenty, } \\
\text { wpisy do rejestrów działalności gospo- } \\
\text { darczej, wywiady. }\end{array}$ & $\begin{array}{l}\text { Reporterom tabloidów na ogół wystar- } \\
\text { czają poufne informacje od informa- } \\
\text { torów. }\end{array}$ \\
\hline $\begin{array}{l}\text { Poziom } \\
\text { sensacyjności } \\
\text { publikacji }\end{array}$ & $\begin{array}{l}\text { Elementy sensacyjności są równoważ- } \\
\text { one przez zachowanie warsztatowych } \\
\text { reguł (prezentację stanowisk stron kon- } \\
\text { fliktu, wyważenie argumentów, opar- } \\
\text { cie na faktach). }\end{array}$ & $\begin{array}{l}\text { Dramaturgia przekazu wydaje się być } \\
\text { podstawowym kryterium przydatności. }\end{array}$ \\
\hline $\begin{array}{l}\text { Rzetelność } \\
\text { w relacjono- } \\
\text { waniu } \\
\text { wydarzeń }\end{array}$ & $\begin{array}{l}\text { W dziennikarstwie dochodzeniowym } \\
\text { nie do pomyślenia jest umieszczanie w } \\
\text { materiale prasowym elementów fikcyj- } \\
\text { nych (jeśli się zdarza, to incydental- } \\
\text { nie). }\end{array}$ & $\begin{array}{l}\text { W przypadku tabloidów jest przyzwo- } \\
\text { lenie na wplatanie do publikacji ele- } \\
\text { mentów fikcyjnych, fabrykowanie } \\
\text { treści publikacji (postaci, miejsc, cyta- } \\
\text { tów). }\end{array}$ \\
\hline $\begin{array}{l}\text { Procedura } \\
\text { pracy nad } \\
\text { tekstem }\end{array}$ & $\begin{array}{l}\text { Reporterzy śledczy przygotowując } \\
\text { materiał przechodzą zwykle cztero- } \\
\text { stopniowy proces weryfikacji i opraco- } \\
\text { wania zdobytych informacji. }\end{array}$ & $\begin{array}{l}\text { W tabloidach, gdzie liczy się walka } \\
\text { z czasem i konkurencją, informacje nie } \\
\text { podlegają wielostopniowej weryfika- } \\
\text { cji, a ich przydatność mierzy się z punk- } \\
\text { tu widzenia sensacyjności materiału. }\end{array}$ \\
\hline
\end{tabular}

Źródło: M. J. Ehrlich, The Journalism of Outrageousness: Tabloid Television News vs. Investigative News, „Journalism \& Mass Communication Monographs” 1996, no. 155.

Powyższe zestawienie nie stanowi, rzecz jasna, zamkniętej liczby różnic. W dziennikarstwie śledczym cechą charakterystyczną jest samodzielne, często bardzo żmudne i długotrwałe ustalanie prawdy, niedające 
jednak gwarancji końcowego sukcesu w postaci publikacji. Natomiast w tabloidach reporterzy działający pod presją czasu i konkurencji niemal natychmiast przekazują do druku zasłyszane plotki lub informacje pochodzące z przecieków, nie próbując nawet potwierdzić ich prawdziwości ${ }^{39}$. Zatem to, co dla reportera dochodzeniowego jest początkiem drogi nad ewentualnym tekstem (plotka, przeciek), w przypadku mediów brukowych stanowi niemal natychmiast kanwę publikacji. A to prowadzi, przy częstym jednoczesnym fabrykowaniu faktów, postaci i cytatów, do deprecjacji nie tylko samego materiału prasowego, ale również wydarzenia w nim opisywanego. Jak zauważył słusznie Robert Williams,

„duża liczba plotkarskich zarzutów powoduje, że skandal traci spójność i tożsamość oraz wydaje się rozmazany" ${ }^{40}$.

Dlaczego więc tabloidy tak chętnie nadużywają przyrostka „-gate” w swoich doniesieniach? Zdaniem Davida Williamsona może to być forma sugerowania odbiorcom, że mają do czynienia z efektem pracy śledczych reporterów, którzy właśnie odkryli celowo ukryty przed opinią publiczną przysłowiowy „wierzchołek góry lodowej”, dotyczący ważnych społecznie kwestii. Jego pojawienie wraz z demaskacją kontrowersyjnych treści może prowadzić do skandalu, który zniszczy negatywnego bohatera, a autorowi tych rewelacji prasowych otworzy „drzwi do kariery"41. Nie bez znaczenia jest, jak można wywnioskować na podstawie zachowań w tym zakresie redakcji prasowych, dążenie do maksymalizacji zysków ze sprzedaży, a co za tym idzie, również z reklam. Sensacyjne doniesienia, w tym przede wszystkim te dotyczące intymnej strony życia osób znanych, wzbudzają zainteresowanie nawet postronnych odbiorców, którzy kierując się ciekawością decydują się na incydentalny, jednorazowy zakup egzemplarza gazety (w takich przypadkach nakłady oraz sprzedaż wydań wydatnie ulegają zwiększeniu). Jak zauważył słusznie John B. Thompson:

„Skandal jest pianą na powierzchni życia społecznego i politycznego, bitą przez pozbawionych skrupułów dziennikarzy i instytucje

39 Prawdziwe śledztwa dziennikarskie potrzebują odpowiednich zasobów (ludzkich, finansowych, organizacyjnych) i czasu, a tego w mediach jest zawsze zbyt mało (M. Just, R. Levine, K. Regan, Investigative journalism despite the odds, „Columbia Journalism Review", November/December 2002).

40 R. Williams, Political Scandals in the USA, Edinburgh-Chicago 1998, s. 2.

41 D. Williamson, 'Gate' expectations are no longer what they used to be, op. cit. 
medialne, które wiedza, jak wykorzystać seksualną nieostrożność ludzi u władzy, by szybko się wzbogacić. Co gorsza. Ta piana przesłania to, co jest naprawdę istotne w życiu społecznym i politycznym, odwracając uwagę od naprawdę znaczących zagadnień” ${ }^{\text {"2 }}$.

Dla redakcji publikującej sensacyjne materiały prasowe ważna jest również liczba cytowań, która obecnie stanowi jedno z istotniejszych kryteriów oceny tytułu na rynku. Im częściej publikacje gazety przywoływane są w tekstach konkurencyjnych mediów, tym lepsza pozycja danego medium i bardziej znaczący potencjalny wpływ na rzeczywistość. Przy okazji tego typu doniesień można także wykreować wizerunek danego tytułu prasowego, jako „niezależnego”, „wolnego od panujących aktualnie układów między światem mediów a polityki i biznesu", mającego na względzie przede wszystkim interes odbiorcy ${ }^{43}$. Nie bez znaczenia jest również autokreacja dziennikarza.

„Dziennikarze skandalizujący z sukcesem cieszą się wysokim poważaniem przede wszystkim we własnym środowisku zawodowym. [...] We wszystkich wypadkach koledzy podziwiaja jednak nie tylko ich osiagnięcia dziennikarskie, ale także pełnioną przez nich rolę społeczna, gdyż udaje im się to, czego pragnie wielu dziennikarzy, choć tylko nieliczni otwarcie się do tego przyznają"44.

Czy zatem tego typu sztuczne wzmocnienie sygnału wysyłanego do odbiorców wpływa negatywnie na efekty pracy dziennikarzy śledczych? Niewątpliwie tak, o czym przekonują nie tyko współczesne doświadczenia, ale również historia. Wystarczy przywołać losy muckrakingu ze

42 J. B. Thompson, Skandal polityczny. Władza i jawność w epoce medialnej, op. cit., s. $17-18$.

${ }^{43}$ K. A. Papadopoulos, K. Widestedt, The Mediated Visibility of Political Scandal: How a crayfish party turned a Swedish minister into a poodle, paper presented at the International Communication Association Conference in Dresden 2006, http://www.oru.se/PageFiles/24075/Paper\%20Mediated\%20visibility\%20nr\%2014.pdf, 18.10.2009. Zdaniem autorek polityczne skandale są oznaką władzy mediów w kształtowaniu opinii publicznej i ustalaniu hierarchii wydarzeń, ale również stanowią dowód na nieodzowność prasy jako psa stróżującego demokracji, będąc jednocześnie formą legitymizacji dziennikarzy jako samozwańczej reprezentacji społeczeństwa (s. 4).

${ }^{44}$ H. M. Kepplinger, Mechanizmy skandalizacji w mediach, Kraków 2008, s. 123-124. Zdaniem Kepplingera następne pokolenia dziennikarzy wychowane w tradycji skandalu mogą wykazywać duże skłonności do skandalizacji różnych patologii (s. 131). 
„złotego okresu publicznej służby dziennikarstwa"45. Blisko dwudziestoletni czas rozkwitu dziennikarstwa śledczego uwidocznił nie tylko siłę wpływu mediów na życie polityczne, społeczne i gospodarkę ${ }^{46}$. Umożliwił jednocześnie powstanie licznej grupy tytułów stricte muckrakerskich, przynoszących ich właścicielom znaczne dochody ${ }^{47}$. Jednak w połowie drugiej dekady XX stulecia zainteresowanie czytelników publikacjami ujawniającymi patologie życia publicznego osłabło na tyle, że w połączeniu z innymi wydarzeniami oznaczało kres wielkości dziennikarstwa śledczego w tamtym wydaniu ${ }^{48}$. Przesyt treściami o negatywnych zjawiskach doprowadził wówczas do zmęczenia odbiorców.

45 D. L. Protess, F. Lomax Cook, J. C. Doppelt, J. S. Ettema, M. T. Gordon, D. R. Leff, P. Miller, The Journalism of Outrage. Investigative Reporting and Agenda Building in America, New York-London 1991, s. 35.

${ }^{46}$ W książce The Era of the Muckrakers Cornelius C. Regier wskazywał na osiagnnięcia dochodzeniowego dziennikarstwa w okresie muckrakingu. Podana przez niego lista reform przeprowadzonych między rokiem 1900 a 1915 jest imponująca: w niektórych stanach zniesiono system zesłańców i robotników przymusowych, podjęto się reform więziennictwa, w 1906 roku uchwalono ustawę federalną określająca standardy jakości przy wyrobie żywności, przepisy dotyczące praw pracujących dzieci zostały zaadoptowane przez wiele stanów, w 1906 roku przyjęto pierwszą Federal Employers' Liability Act, następną w 1908 roku, którą znowelizowano w 1910 roku, określono wielkość rezerw obszarów przeznaczonych pod zalesianie, w 1902 roku uchwalono Newlands Act, wprowadzono politykę ochrony zasobów naturalnych, część stanów wprowadziła przepisy o czterdziestogodzinnym tygodniu pracy dla kobiet, zakazano zakładów na wyścigach konnych, dwadzieścia stanów wprowadziło między rokiem 1908 a 1913 Mothers' Pension Act (emerytury dla samotnych matek), dwadzieścia pięć stanów uchwaliło w 1915 roku Workmens' Compensation Act (ubezpieczenia od nieszczęśliwych wypadków w pracy), w 1913 roku uchwalono XVI poprawkę do Konstytucji o podatku dochodowym, podzielono spółki Standard Oil i Tobacco, wodospad Niagara oraz Alaska zostały uratowane przed chciwością korporacji, wprowadzono korzystniejsze przepisy z zakresu ubezpieczen (C. C. Regier, The Era of the Muckrakers, The University of North Carolina Press 1932, s. 203).

47 Do najbardziej znanych czasopism muckrakerskich tamtego okresu należały: „Collier's”, „Everybody's”, „McClure's”, „Cosmopolitan”, „Arena, Hampton's”, „The Independent”, „Pearson's”, „Success”, „The American Magazine”, „Munsey’s”, „Ladies' Home Journal”, „Good Housekeeping”. Pierwszych pięć historyk Frank Luther Mott zaliczył do grona najbardziej wpływowych ówczesnych tytułów tego segmentu prasy (M. H. Beasley, The Muckrakers and Lynching: A Case Study in Racial Thinking, paper presented at the Annual Meeting of the Association for Education in Journalism and Mass Communication, Corvallis, 6-9.08.1983, s. 2).

48 Zob. W. Adamczyk, Dziennikarstwo śledcze w świecie - status, instytucjonalizacja, przyszłość, w: Polubić dziennikarstwo, red. S. Zakrzewski, Poznań 2009. 
Obecnie podobny skutek może wywołać skandalizowanie dużej części wydarzeń nagłaśnianych w mediach. Dzieje się to ze szkodą dla dziennikarstwa śledczego. Pod wpływem tabloidowego stylu prezentacji informacji stało się ono niejako dobrem powszechnym. Oznacza to, że nawet ujawnienie poufnych treści o znikomym znaczeniu dla biegu spraw państwowych klasyfikowane jest przez same redakcje jako dziennikarstwo śledcze, czego najlepszym przykładem jest właśnie zjawisko „gatemanii”. Cytowany wcześniej John B. Thompson zwraca uwagę na zatarcie podziału pomiędzy różnymi rodzajami tajemnic odkrywanych przez dziennikarzy i szkodę, jaką to ze sobą niesie dla prawdziwych śledztw.

„Kiedy zaakceptowano, że zasłony skrywające wyższe poziomy władzy mogą zostać rozsunięte, bardzo trudno było utrzymać ostry podział na sekrety związane ze sprawowaniem władzy i te dotyczące prowadzenia się w życiu prywatnym. Dziennikarstwo śledcze łatwo mogło zmienić się w lubieżne relacjonowanie wydarzeń, w których ukrywane aspekty sprawowania władzy byłyby wymieszane z ukrywanymi aspektami życia osób ją sprawujących”49.

Ów nieklarowny podział, wzmocniony dodaniem przyrostka „-gate”, fałszywie może sugerować odbiorcom, poprzez nawiązanie do skandalu Watergate, równoważność ustaleń mediów w różnych nagłaśnianych przez nie sprawach ${ }^{50}$. Tym samym, poprzez konotacje ze sławną afera, niemal każde ujawnienie nawet najbardziej banalnego zdarzenia zyskuje nominalnie znaczenie. W praktyce jednak prowadzi do deprecjacji ustaleń prawdziwych dochodzeń dziennikarskich, co prawdopodobnie jednocześnie chciał osiagnąć W. L. Safire, pomysłodawca ,gatemanii”. Joel H. Silbey, historyk z Cornell University uważa, że przyrostek ,-gate” służy głównie do dramatyzowania relacjonowanych przez media historii, a jego wykorzystanie w świecie polityki ma wywołać poczucie zagrożenia i strachu. A wszystko to poprzez proste skojarzenie z traumą wywołaną skandalem Watergate, który na równi wstrząsnął posadami

49 J. B. Thompson, Skandal polityczny. Władza i jawność w epoce medialnej, op. cit., s. $141-142$.

50 Zob. R. Rieder, Gate of Hell, op. cit. Sam Dash, były szef doradców senackiej Komisji ds. Watergate, później również konsultant prokuratora specjalnego Kennetha Starra w sprawie Whitewater stwierdził: „Kiedy ludzie słyszą to rozprzestrzenianie się »gates« czują, że prasa mówi im - to jest takie samo jak Watergate, a cokolwiek stało się synonimem Watergate straciło swoje znaczenie" (S. Revah, Gate Gate, „American Journalism Review”, September 1997). 
instytucji władzy, co społeczeństwem USA ${ }^{51}$. Stwierdzenia te znajdują uzasadnienie w praktyce działania mediów. Wystarczy przywołać przykłady afer, które ilustrują ten niekorzystny trend ostatnich dziesięcioleci:

a) Kennygate - sprawa opisana w 2006 roku przez dziennik „The Irish Independent", dotycząca sporu pomiędzy jednym z najlepszych w Irlandii prezenterów radia i telewizji a jego sąsiadem $^{52}$;

b) Passportgate - w incydent zamieszanych było trzech pracowników Departamentu Stanu USA, którzy w nielegalny sposób weszli w posiadanie informacji pochodzących z dokumentów dotyczących kandydata na urząd prezydenta, Baracka Obamy, w tym jego paszportu $^{53}$;

c) Wardrobe-gate - skandal związany z wydatkami Sarah Palin, kandydatki w wyborach na urząd wiceprezydenta USA, której media wytknęły zakupy markowej odzieży na kwotę $\$ 150000^{54}$;

d) Winegate - w aferę zamieszanych było kilku sprzedawców wina Bordeaux, którzy w butelkach z etykietami drogiego trunku oferowali alkohol gorszego gatunku;

e) Sexy Photo Gate - intymne zdjęcia aktora i piosenkarza z Hong Kongu, Edisona Chen, oraz jego przyjaciół zostały rozesłane za pośrednictwem Internetu ${ }^{55}$;

f) Terrygate - piłkarz londyńskiego klubu Chelsea FC uwiódł narzeczoną innego gracza tej drużyny - Wayne'a Bridge'a, a stało się to w domu tego ostatniego 56 ;

g) Quailgate - incydent z postrzeleniem przez wiceprezydenta USA, Dicka Cheneya, prawnika z Austin, Harry’ego Whittingtona podczas

51 A. Clymer, Watergate Legacy: More Than a Tired Suffix, „,The New York Times", 17.06.2002.

52 A. M. Mooney, Tabloidization and the Irish Press Media. An Analysis of How the Irish Independent Reacted to the Introduction of Irish Version of British Tabloids, University of Leeds, September 2008, s. 25.

53 H. Kurtz, Passportgate, ,The Washington Post”, 21.03.2008.

54 Sarah Palin cleared in pricey - wardrobe-gate: Federal Election Commission (FEC) dismisses complaint, „The Daily News”, 19.05.2009.

${ }_{55} \mathrm{~K}$. Quinn, It's time to close the gate before someone takes offence, „The Age”, 24.06.2009.

56 Is John Terry's sacking about morality or just a bad smell?, „The Guardian”, http://www.guardian.co.uk/football/blog/2010/feb/05/john-terry-wayne-bridge-saga, 7.03.2012. 
polowania na przepiórki, o którym informację opinii publicznej podano z jednodniowym opóźnieniem ${ }^{57}$;

h) Helicoptergate - afera ze współpracownikiem Williama Jeffersona „Billa” Clintona, Davidem Watkinsem, który korzystał z prezydenckiego śmigłowca udając się na pole golfowe, co obciążało dodatkowo kieszenie podatników ${ }^{58}$;

i) Vandalgate - tym mianem określono zachowanie członków personelu Białego Domu z administracji W. J. „Billa” Clintona, którzy odchodząc wraz z końcem kadencji prezydenta dopuścili się aktów wandalizmu w pomieszczeniach służbowych, pozostawiając swoim następcom śmieci oraz tabliczki ze sprośnymi wiadomościami ${ }^{59}$;

j) Vanessagate - w 1999 roku, gdy okazało się, że w telewizyjnym show Vanessy Feltz pokazywano wynajętych aktorów odgrywających inne postaci, audycje zawieszono, choć sama prowadząca nie miała podobno wpływu na to, kogo zapraszano do studia;

k) Becksgate - do mediów trafiła informacja o romansie znanego piłkarza, Davida Beckhama, z Rebeccą Loos, czego dowodem były ujawnione wiadomości tekstowe;

1) Bastardgate - w lipcu 1993 roku John Major, premier Wielkiej Brytanii, po wygranym w Izbie Gmin głosowaniu nad wotum zaufania udzielił wywiadu reporterowi telewizyjnemu, Michaelowi Brunsonowi. Po zakończeniu wywiadu, już przy wyłączonym mikrofonie, J. Major poskarżył się dziennikarzowi na trzech eurosceptycznie nastawionych ministrów swojego gabinetu i nazwał ich bękartami. Rozmowa ta była jednak podsłuchiwana przez osoby postronne, ponieważ nie wszystkie mikrofony zostały wyłączone. Treść wypowiedzi premiera wyciekła do prasy i doprowadziła do skandalu;

m) Piegate - skandal z udziałem członka szkockiego parlamentu i ministra kultury, Franka McAveety, którego przyłapano na kłamstwie podczas konferencji prasowej. Tłumaczył on swoje spóźnienie na spotkanie z dziennikarzami koniecznością uczestnictwa w uroczystości wręczenia nagród w Arts Council, jednak kilku reporterów widziało go kilka minut wcześniej podczas posiłku w parlamentarnej stołówce. Po ujawnieniu tej informacji został on zdymisjonowany;

57 C. Krauthammer, Quell Quailgate. Cheney's Call Was Wrong but Understandable, „The Washington Post”, 17.02.2006.

58 P. Cockburn, Helicopter scandal hits White House, „The Independent”, 27.05.1994.

59 J. McLean, Vandalgate at the White House, „The Herald”, 26.01.2001. 
n) Squidygate - w sierpniu 1992 roku tabloid „The Sun” upublicznił szczegóły rozmowy telefonicznej księżnej Diany z jej byłym kochankiem, James'em Gilbey, dotyczącej problemów w książęcej rodzinie;

o) Camillagate - w listopadzie 1992 roku w Wielkiej Brytanii do prasy wyciekła podsłuchana nocna rozmowa telefoniczna następcy tronu, księcia Karola, z jego ówczesną zamężną kochanką, Camillą Parker-Bowles, podczas której pojawiły się stwierdzenia o podłożu seksualnym (Karol miał powiedzieć, że mógłby być jej tamponem, byle tylko być przy niej);

p) Nipplegate - 1 lutego 2004 roku, w przerwie transmisji finału Super Bowl w telewizji należącej do sieci CBS, pokazywano występ gwiazd muzyki - Janet Jackson i Justina Timberlake'a. Podczas wykonywania wspólnie utworu muzyk zerwał fragment odzieży piosenkarki odsłaniając jej pierś. W efekcie skandalu tysiące Amerykanów napisało skargi do Federal Communications Commission (FCC), która nałożyła na stację wysoką karę finansową ${ }^{60}$;

q) Gurugate - żona amerykańskiego prezydenta, Hillary Rodham Clinton, za namową Jean Houston prowadziła w Białym Domu seanse spirytystyczne, podczas których miała rozmawiać z historycznymi postaciami, w tym z Gandhim i Eleonor Roosevelt ${ }^{61}$;

r) Henrygate - takim mianem nazwały media skandaliczne zachowanie piłkarza francuskiego, Thierry’ego Henry. Grając z opaską kapitana reprezentacji w meczu barażowym z Irlandią, który miał przesądzić o awansie do finałów mistrzostw świata, zagrał piłkę ręką do kolegi z drużyny, a ten zdobył zwycięskiego gola ${ }^{62}$;

s) Weinergate - afera z czerwca 2011 roku, kiedy media ujawniły, że kongresmen Anthony Weiner miesiąc wcześniej wysyłał przez serwis społecznościowy Twitter maile do kobiety ze swoimi zdjęciami (był na nich półnagi). A. Weiner najpierw temu zaprzeczył, później jednak w obliczu przedstawionych publicznie dowodów zrezygnował z pracy w Kongresie ${ }^{63}$.

60 Media Scandal: From Watergate to Rustygate, „The Independent”, 25.04.2005.

61 S. Revah, Gate Gate..., op. cit.

62 D. O'Kelly, Hopefully, FIFA puts end to Henrygate affair, „The Score”, 18.01.2010.

63 D. Alfarone, The Women of Weinergate: Anthony Weiner's Sexting Mates, „Chicago Tribune", 7.06.2011; A. Heffner, The Anthony Weiner scandal doesn't merit a ' gate'..., op. cit. 
Powyższe wydarzenia z pewnością nie zasługiwały na nazwę z przyrostkiem ,-gate”, bowiem ich tematyka oraz waga z punktu widzenia państwa i społeczeństwa w żaden sposób nie daje się porównać do skandalu Watergate. Należy przyznać rację Michaelowi Schudsonowi, według którego skandale koncentrując uwagę odbiorców na sprawach incydentalnych trywializują publiczny dyskurs ${ }^{64}$. Biorąc pod uwagę fakt, że przykłady te stanowią jedynie niewielką próbkę zjawiska ,gatemanii”, trudno nie dostrzec problemu dla środowiska mediów. Dalsze popularyzowanie tego trendu może w przyszłości doprowadzić do sytuacji, gdy materiały prasowe opatrzone tak konstruowanymi tytułami nie będa wywoływały pożądanych efektów z powodu ich nagminnego charakteru. Koresponduje to z koncepcją teorii kary Heinricha Popitza:

„Jeśli zbyt wiele osób zostanie postawionych pod pręgierzem, to nie tylko pręgierz traci moc odstraszania, lecz także fakt naruszenia normy traci charakter wyjątkowości, a tym samym charakter czynu, przez który coś zostaje »złamane, rozbite«" ${ }^{65}$.

Wśród blisko dwustu przypadków znanych autorowi publikacji z wykorzystaniem przyrostka ,-gate” tylko niewielka liczba zasługuje na takie specjalne oznaczenie, nawiązujące do pierwowzoru z lat 70. Są to na ogół powszechnie znane i nagłośnione przez media wydarzenia, których ujawnienie stało się niejednokrotnie bodźcem do śledztw prowadzonych przez wyspecjalizowane agendy państwa: Koreagate ${ }^{66}$, Irangate $^{67}$, Vince Fostergate ${ }^{68}$,

${ }_{64}$ M. Schudson, The Sociology of News, New York-London 2003, s. 103.

${ }^{65}$ H. M. Kepplinger, Mechanizmy skandalizacji w mediach..., op. cit., s. 124-125. Kepplinger nie podziela tego zdania, bowiem specyficzny krąg sprawców sprawia, że nawet przy licznej grupie osób będących obiektem skandalizacji „pręgierz” nie traci mocy odstraszania.

${ }^{66}$ N. Cohen, The Smoking Lexicon, „New York Magazine”, 5.02.1996; J. Green, Dictionary of Jargon..., op. cit., s. 606.

67 J. Diaz, Will 'gate-gate' ever cease?, „San Francisco Chronicle”, 25.07.2010. Skandal ten miał $\mathrm{w}$ mediach jeszcze inne określenia: Contragate, Iran-Contra, Iran-Contra Affair (chodziło o nielegalną sprzedaż przez administrację Ronalda Reagana broni do Iranu, by uzyskać fundusze na finansowanie w Nicaragui antyrządowych oddziałów zbrojnych nazywanych Contras).

${ }^{68}$ E. Alterman, Sound of fury: the making of the punditocracy, Cornell University 1999, s. 268 (Vince Foster był prawnikiem B. Clintona. Prasa powiązała tajemnicze okoliczności samobójstwa Fostera z usuwaniem w jego biurze - już po śmierci - dowodów w sprawie Whitewater i celowym opóźnianiem przez Bernarda Nussbauma, współpracownika prezydenta, dostępu do biura prawnika detektywom). 
Sarkogate $^{69}$, Monicagate ${ }^{70}$. Przykłady te oczywiście nie stanowią wyczerpującej listy, ale są dobrą ilustracją znaczącej różnicy jakościowej w zestawieniu z wcześniej przywołanymi przypadkami wykorzystywania przyrostka ,-gate” w mediach.

Skandalizacja treści, odwołująca się do tradycji Watergate, może, na co zwracają uwagę Benjamin Ginsberg i Martin Shefter, stanowić oręż upolitycznienia i być wykorzystywana do dyskredytowania przeciwników politycznych $^{71}$. W dodatku, co podkreśla Enrique Perruzzotti, w coraz większej liczbie współczesnych skandali medialnych w procesie zbierania informacji trudno dopatrzyć się elementów pracy własnej dziennikarza. Sensacyjne doniesienia są raczej wynikiem przecieku ze świata polityki lub służb specjalnych, a to sprawia, że tego typu działalność bardziej przypomina dziennikarstwo denuncjacji niż śledcze ${ }^{72}$. A z pewnością dla dobra tego ostatniego skandal powinien nadal pozostawać środkiem do osiagnięcia celu ważnego z punktu widzenia państwa

${ }^{69}$ G. Dobiecki, Sarkogate? Uchowaj Boże!, „Wprost” 2010, nr 29. Media powiązały prezydenta Francji z Liliane Bettencourt, dziedziczką imperium kosmetycznego 1'Oreal. Miała ona skorzystać, dzięki znajomości ministra skarbu, Erica Woertha, z możliwości zwrotu części podatku (dostała go z nadpłaty 30 milionów Euro). Dziennikarze ujawnili, że żona ministra była zatrudniona w jej koncernie. Dalszych sensacyjnych informacji udzieliła mediom Claire Thibout, księgowa w firmie Bettencourt. Według niej Nicolas Sarkozy, jeszcze jako mer podparyskiej gminy, w której ona mieszkała, otrzymywał od niej regularnie koperty z gotówką, a na jego kampanię prezydencką przekazała ona za pośrednictwem ministra Woertha 150000 Euro, co jest we Francji uznawane za przestępstwo.

70 Jim Doyle, były szef biura w Waszyngtonie dziennika „Boston Globe” oraz specjalny asystent $\mathrm{w}$ postępowaniu w sprawie Watergate, poproszony przez redakcję „American Journalism Review” o porównanie tego skandalu ze wspomnianą aferą z lat 70. stwierdził, że różnica jest przede wszystkim w sposobie przedstawienia. Edycja skandalu Watergate była według niego powolna i ostrożna, natomiast w sprawie Monicagate media zaprezentowały tak zwany beat reporting (S. Doster, Watergate vs. Monicagate, „American Journalism Review”, January/February 1999). Przykłady poważnych afer z innych państw można znaleźć w: B. D. Joseph, Yet more on -gate words: a perspective from abroad, „American Speech” 1992, no. 67; W. W. Schumacher, More on gate, „American Speech” 1988, no. 63.

71 B. Ginsberg, M. Shefter, Politics by Other Means. Politicians, Prosecutors, and the Press from Watergate to Whitewater, New York-London 1999, za: E. Perruzzotti, Media Scandals and Social Accountability. Assessing the Role of the Senate Scandal in Argentina, s. 4, http://www.utdt.edu/upload/-115332700772067400.pdf, 7.06.2008.

72 E. Perruzzotti, Media Scandals and Social Accountability. Assessing the Role of the Senate Scandal in Argentina..., op. cit., s. 12. 
i społeczeństwa w wyniku samodzielnego, drobiazgowego dochodzenia dziennikarskiego, a nie „drogą na skróty” wypaczającą obraz rzeczywistości.

\title{
'Gatemania' as an example of the tabloidization of investigative journalism
}

\begin{abstract}
Summary
The author of the paper analyzes the phenomenon of 'gatemania' in the mass media, paying particular attention to its influence on investigative journalism. Both the origins and evolution of this disturbing trend are discussed, beginning with William Lewis Safire. The author presents a broad range of definitions of the notion of 'gatemania', coined by the British journalist working for The Guardian, David Marsh. The paper enumerates a number of media scandals the media have referred to using the -gate suffix, ordering them by the three most frequent criteria. The relations between the stages of a classical model of muckraking and the components of a scandal are discussed, along with the elements that distinguish investigative journalism from tabloid-like journalism. In the opinion of the author, excessive use of the -gate suffix serves the purpose of the tabloidization of the message and is usually inadequate in relation to the event described; another reason for its use is to mislead readers, by implying that the articles are a result of investigative journalism.
\end{abstract}


